\title{
Morphotectonic of Tang-e-Sarhe Catchment and its Effect on Morphology and Behavior of the River, Nikshahr, Southeast of Iran
}

\author{
Mahmoud Yargholi and Kazem Shabani Goraji* \\ Department of Geology, Islamic Azad University, Zahedan Branch, Zahedan, Iran; \\ yargholi62@yahoo.com,ksg1354@yahoo.com
}

\begin{abstract}
The catchment of Tang-e-Sarhe river is located about $60 \mathrm{~km}$ northwest of Nikshahr in southern Sistan and Baluchistan Province in Southeast of Iran. This study aims to evaluate the active tectonic of the area using geomorphic indices. The research instruments include Landsat satellite images, digital, topographical and geological maps of the area and Arc GIS software. Tang-e-Sarhe is divided into two distinct sub-basins and the active tectonic parameters of the catchment including hypsometric integration, asymmetry factor, transverse topographic asymmetry factor, Mountain-Front Sinuosity and ratio of valley-floor to valley height are determined. Moreover, the changes in the river bed and its pattern are also investigated. Thus, cross-sections for waterways was calculated and their positions were recorded using GPS and then, transferred to the maps. Curvature coefficient index indicated that river meander, as a result of high tectonic activities in this area, a decrease in bed erosion and an increase in the erosion of the sides, tends to develop in upstream direction. According to Pit's tortuosity coefficient table, the tortuosity coefficient of Tang-e-Sarhe River is 1.24, showing a sinuosity. Indices also reveal that sub-basin (1) is among the most active catchments regarding the tectonic activities while, subbasin (2) shows less activity than sub-basin (1) and is relatively active. Also, the tectonic activities are decreased from north to south.
\end{abstract}

Keywords: Morphotectonic, Active Tectonic, Makran Zone, Tang-e-Sarhe, Nikshahr, Iran

\section{Introduction}

Active tectonic investigates the dynamic processes influencing shaping the earth and its prospects ${ }^{13}$. Geomorphic indices are particularly used to study active tectonics? Rivers, as one of the most important landscapes on the earth, show sensitivity to tectonic activities and are studied to evaluate the active tectonics ${ }^{8}$. The shape and pattern of the river undergo changes by various factors including geological and hydrological factors and causes instability of the river channel, followed by morphological changes and bank erosion ${ }^{11}$. Meandering, crossing faults and some disjunctions and diversions along the river stream, especially in the flood plain, seems to be affected by active tectonic activities of the river. The effect of active tectonic on the rivers can be seen in the form of local extension of the meanders, diversion and disjunction of the channel, broadening and narrowing of the channel bed and sudden changes in streams in different periods ${ }^{10}$. The most fundamental effect of tectonic activities on the river and river valleys is a change in valley slope and pattern channels are sensitive indicators of valley-slope change ${ }^{12}$.

*Author for correspondence 
Yet, another concern is the measurements based on calculating geomorphic indices and other parameters and using topographic maps, aerial and satellite images and field work. This research aims to examine the effect of active tectonic of the area on the evolution of the landform using geomorphic indices and studying geomorphic evidence affected by active tectonic of the area. Tang-eSarhe area is located in the structural-sedimentary zone of Makran and is of great importance due to its presence in conflict area and high rate of main tension in the area ${ }^{3}$. Regarding the high tectonic activities of the area, this study examines the effect of tectonic activities on changing the characteristics of Tang-e-Sarhe catchment.

\section{Method and Material}

To study the morphometric indices easily, this study divide Tang-e-Sarhe catchment into two sub-basins based on topographic maps (1:50000), Landsat satellite images (30 and $15 \mathrm{~m}$ ) and geological maps of Nikshahr (1:250000). Topographic maps, aerial and Landsat satellite images and Google earth images taken from the area in the year 2013 are used as information layers in Geographical Information System (GIS). Then, hypsometric indices, asymmetry factor, transverse topographic symmetry, stream length to its slope ratio, MountainFront Sinuosity and Ratio of valley-floor to valley height are calculated. To determine morphometric indices, bed changes and pattern of Tang-e-Sarhe river are also studied. To do so, the cross section is determined in some parts of waterways and their positions are recorded by GPS and transferred to the maps. Curvature coefficient indices and Arc GIS 10.1, Global Mapper and Photoshop softwares are also employed to analyze the collected data. Regarding the resulting tectonic indices, Tang-e-Sarhe river catchment is evaluated with respect to its relative tectonic activities. The mentioned indices are determined for both sub-basins and the findings are adjusted with other active tectonic parameters, and eventually, the results are used to evaluate the active tectonic of the area.

\subsection{Geography of the Studied Area}

Tang-e-Sarhe river catchment covers an area of 168 square kilometers and is located in $60 \mathrm{~km}$ northwest of Nikshahr in Makran Highlands, in Sistan and Baluchistan Province (Figure 1). Figure 2 depicts Ghasr-e-Ghand, Arand and Kahurkan faults crossing the river. This river, extending for $35 \mathrm{~km}$, flows all year and is sustained in dry seasons by local springs. This area has dry and hot climate and rainfalls are influenced by Monsoon fronts of Indian Ocean.

\subsection{Regional Geology}

The studied area located in Makran fold-and-thrust belt in southeast of Iran. Faults of this area indicate east-west

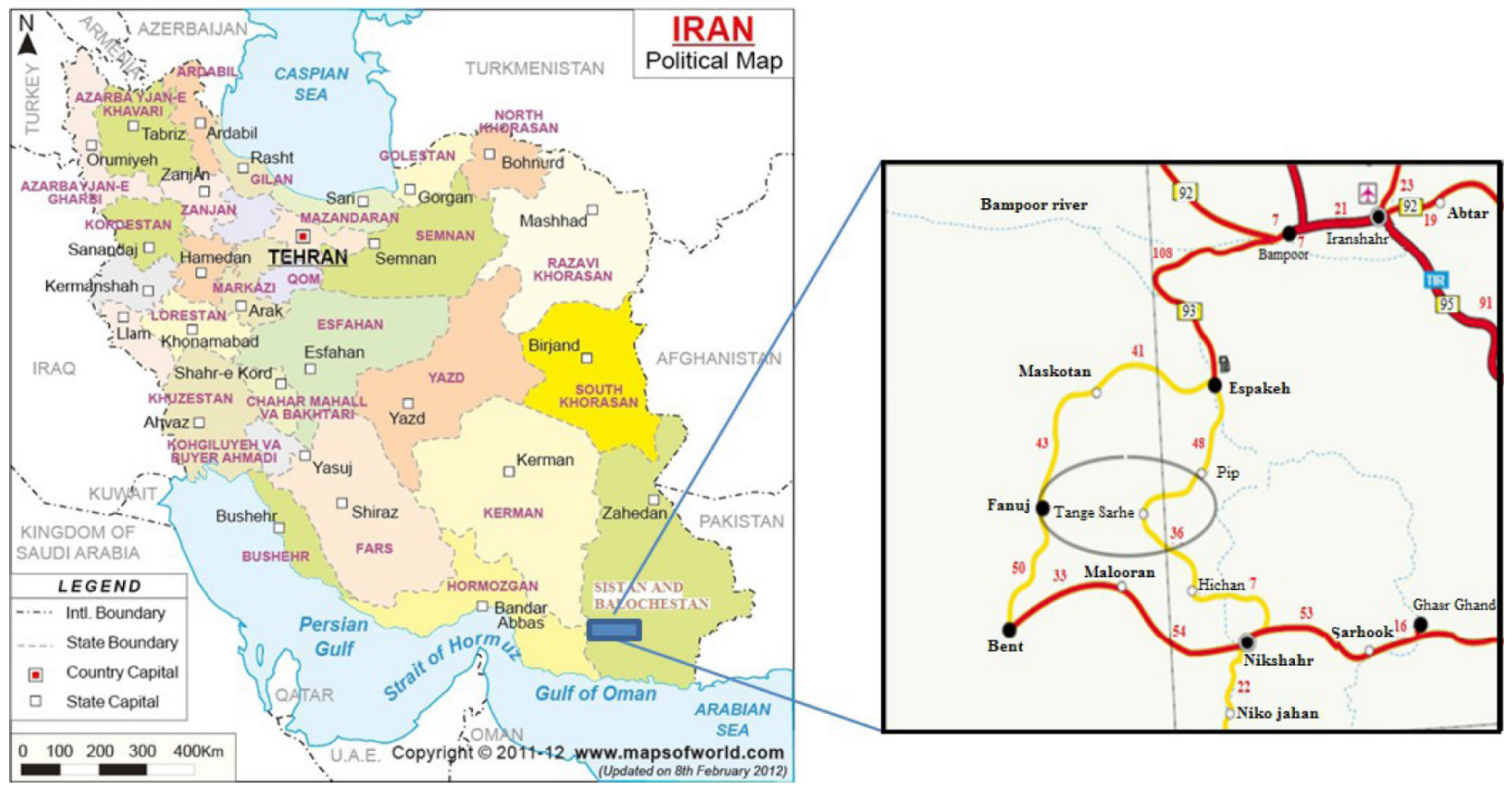

Figure 1. Tang-e-Sarhe area in Sistan and Baluchistan Province. 


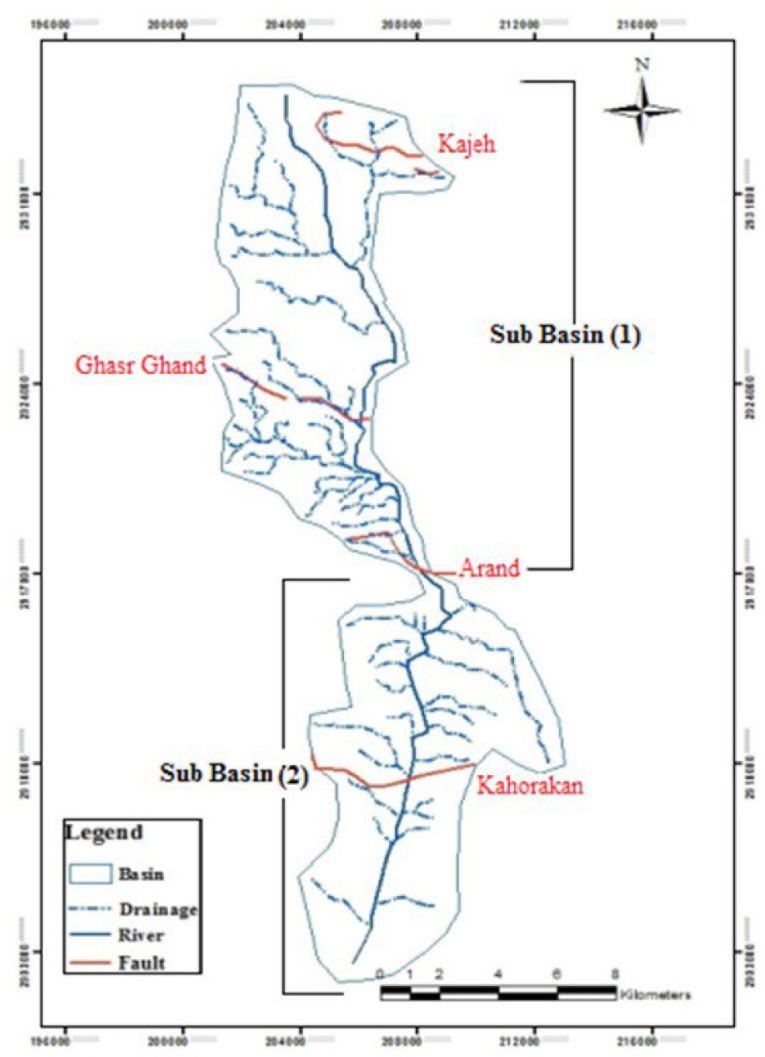

Figure 2. Map of watercourse and faults of Tang-e-Sarhe river catchment. oriented trend and its geomorphology is complex and of great importance due to its extreme tectonic activities ${ }^{1}$. In the northern part of region, the lithology of the low shales has been changed and soft phyllites have created many folds in shear zone. The general face of northern folds resembles small parasites folds with wave length of about $10-20 \mathrm{~cm}$. The dominant lithology of Tang-e-Sarhe river catchment includes sandstone, siltstone, shale, tuff, carbonaceous deposits and alluvial deposits. Much of the sediments found around Nikshahr dates back to Cenozoic age and is composed of flysch and shallow deposits, and as depicted in Fanuj and Tahruei maps, it is extended towards west ${ }^{6}$. Around this area, Nikshahr's quadrangle ophiolitic rocks are referred to as a local mixture. In this area, five informal stratigraphic units of Miocene including Hichan, Ghasr-e-Ghand, Ruksha, Vaziri and Jarut are recognized (Figure 3). Moreover, an informal unit called Whale, relating to Pliocene and Pleistocene, is protruded in this area ${ }^{4}$.

\subsection{Discussion}

To study the tectonic activities of Tang-e-Sarhe river catchment, some important quantitative indices including hypsometric integral, asymmetry factor, transverse topographic symmetry factor, stream length gradient
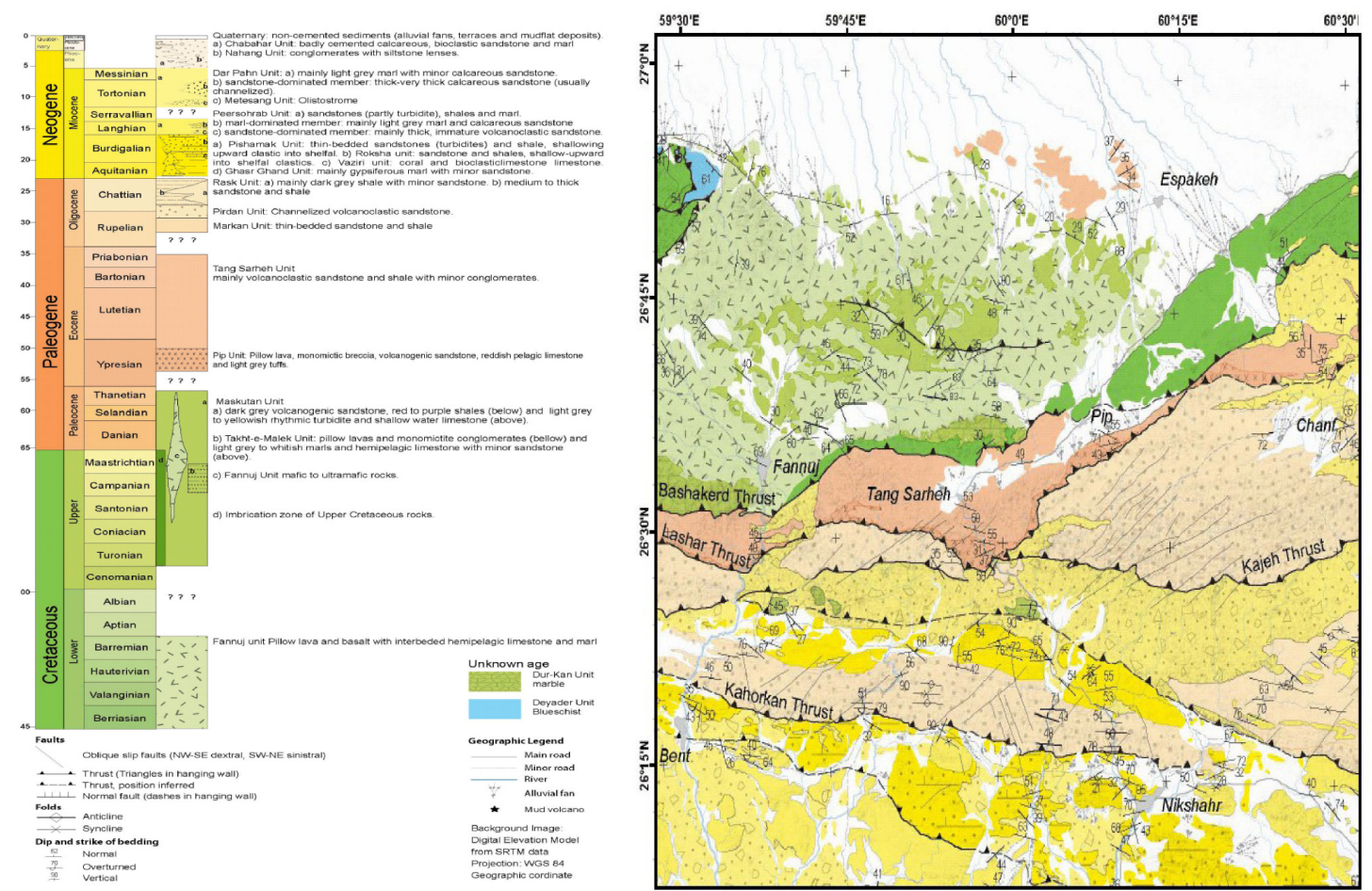

Figure 3. The geological map of the area (1:250000 scale). 
index, mountain-front sinuosity and ratio of valley-floor to valley height are analyzed ${ }^{10}$.

\subsection{Hypsometric Curve and Integral}

Hypsometric curve and integral point to the distribution of the height in a particular place of the earth ${ }^{10}$.

hypsometric integral $=\frac{\text { average height }- \text { minimum height }}{\text { maximum height }- \text { minimum height }}$

The high value of this index refers to the active and young tectonic areas while, the low value connotes the low areas eroded and rarely affected by active tectonic ${ }^{2}$. The catchment considered in this area is divided into two sub-basins and the hypsometric curve and integral are separately calculated for each of them. The amount of hypsometric integral for these sub-basins is obtained

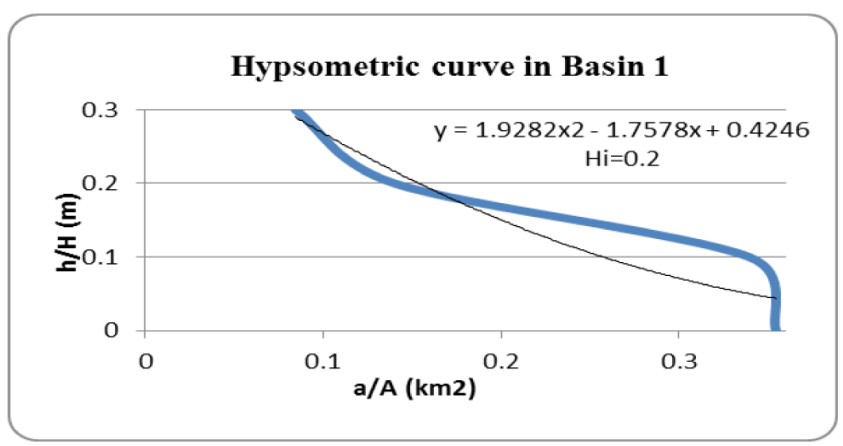

Figure 4. Hypsometric integral in sub-basin (1). through calculating the area below the hypsometric curves the value of this index for sub-basin (1) is 0.2 and 0.6 for sub-basin (2).

Sub-basin (1)

The geographical coordinates for this sub-basin is $26^{\circ}$ $30^{\prime} \mathrm{N}$ and $60^{\circ} 04^{\prime} 85^{\prime \prime} \mathrm{E}$ and its values are presented in Figure 4. Four levels of hypsometric integral are calculated for this sub-basin (Table 1).

Sub-basin (2)

The geographical coordinates for this sub-basin is $26^{\circ}$ $20^{\prime} 86^{\prime \prime} \mathrm{N}$ and $60^{\circ} 06^{\prime} 85^{\prime \prime} \mathrm{E}$ and its values are presented in figure 5. Eight levels of hypsometric integral are calculated for this sub-basin (Table 2).

Convex curve indicates the high activity of the area as well as fault activity and protrusion relating to wrinkling.

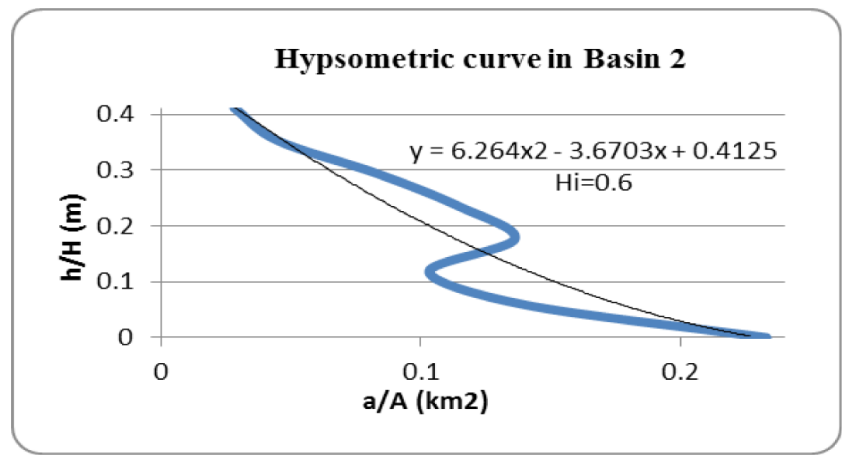

Figure 5. Hypsometric integral in sub-basin (2).

Table 1. Hypsometric curve in sub-basin (1)

\begin{tabular}{lccccc}
\hline $\mathbf{h}(\mathbf{m})$ & $\mathbf{h}_{0}(\mathrm{~m})$ & $\mathbf{h} / \mathrm{H}(\mathrm{m})$ & $\mathrm{a}\left(\mathrm{km}^{2}\right)$ & $\mathrm{A}\left(\mathrm{km}^{2}\right)$ & $\mathrm{a} / \mathrm{A}\left(\mathrm{km}^{2}\right)$ \\
\hline 700 & 0 & 0.636363636 & 32.87 & 92.72 & 0.354508197 \\
800 & 100 & 0.727272727 & 31.47 & 92.72 & 0.339408973 \\
900 & 200 & 0.818181818 & 13 & 92.72 & 0.140207075 \\
1000 & 300 & 0.909090909 & 7.82 & 92.72 & 0.084339948 \\
\hline
\end{tabular}

Table 2. Hypsometric curve in sub-basin (2)

\begin{tabular}{lccccc}
\hline $\mathrm{h}(\mathrm{m})$ & $\mathrm{h}_{0}(\mathrm{~m})$ & $\mathrm{h} / \mathrm{H}(\mathrm{m})$ & $\mathrm{a}\left(\mathrm{km}^{2}\right)$ & $\mathrm{A}\left(\mathrm{km}^{2}\right)$ & $\mathrm{a} / \mathrm{A}\left(\mathrm{km}^{2}\right)$ \\
\hline 500 & 0 & 0 & 18.49 & 79.35 & 0.233018273 \\
550 & 50 & 0.058823529 & 11.1 & 79.35 & 0.139886578 \\
600 & 100 & 0.117647059 & 8.19 & 79.35 & 0.103213611 \\
650 & 150 & 0.176470588 & 10.8 & 79.35 & 0.13610586 \\
700 & 200 & 0.235294118 & 9.1 & 79.35 & 0.11468179 \\
750 & 250 & 0.294117647 & 6.6 & 79.35 & 0.083175803 \\
800 & 300 & 0.352941176 & 3.57 & 79.35 & 0.044990548 \\
850 & 350 & 0.411764706 & 2.24 & 79.35 & 0.028229364 \\
\hline
\end{tabular}


However, concave curve points to the low tectonic activity in the area ${ }^{2}$. In sub-basin (1), convexity initially occurs downward and then goes upward. In sub-basin (2), on the other hand, it is vice versa. The $H_{i}$ value in sub-basin (1) is 0.2 , suggesting the low activity of the area and this value for sub-basin (2) is 0.6 , indicating the high tectonic activity in this sub-basin.

\subsection{Drainage Basin Asymmetry Factor}

The asymmetry factor is used to indicate tectonic tilting at the scale of drainage basin or large areas ${ }^{10}$.

$$
\mathrm{AF}=100\left(\mathrm{~A}_{\mathrm{r}} / \mathrm{A}_{\mathrm{t}}\right)
$$

$A_{r}$ : the area of the right- hand side basin, $A_{t}$ : total area of the drainage basin; AF: asymmetry of basin.

In the studied area, the asymmetry factor is determined for these two sub-basins and its results are presented in Table (3).

In the studied area, the river flows southwards and sub-basins enjoy a northern-southern trend. Thus, the value of $A F$ less than $50(A F<50)$ shows the basin was tilted towards the west and the value of AF greater than $50(\mathrm{AF}>50)$ suggests a tilt towards the east. The evaluation of the drainage basin symmetry using transverse topographic symmetry factor reveals that tilting can be found in both sub-basins and its value in sub-basin (1) is 75.12 and tilt is to east (Figure 6), while it is 45.69 in sub-basin (2) and tilt is to west (Figure 7). It is noteworthy that sub-basin (1) enjoys greater tilting due to thrusting and folding.

\subsection{Transverse Topographic Asymmetry Index}

Transverse topographic asymmetry index is used to calculate and evaluate asymmetry of the basin and is resulted from the following equation ${ }^{10}$

$$
\mathrm{T}=\mathrm{D}_{\mathrm{a}} / \mathrm{D}_{\mathrm{d}}
$$

$\mathrm{D}_{\mathrm{a}}$ : the distance from the midline of the drainage basin to the midline of the active meander belt

$\mathrm{D}_{\mathrm{d}}$ : distance from the basin midline to the basin boundary

Table 3. Asymmetry factor in sub-basin (1) and (2)

\begin{tabular}{lcccc}
\hline Basin & $\mathrm{A}_{\mathrm{r}}(\mathrm{sq} \mathrm{km})$ & $\mathrm{A}_{\mathrm{t}}(\mathrm{sq} \mathrm{km})$ & $\mathrm{AF}$ & Tilting Part \\
\hline 1 & 69.66 & 92.72 & 75.12 & East \\
2 & 36.26 & 79.35 & 45.69 & West \\
\hline
\end{tabular}

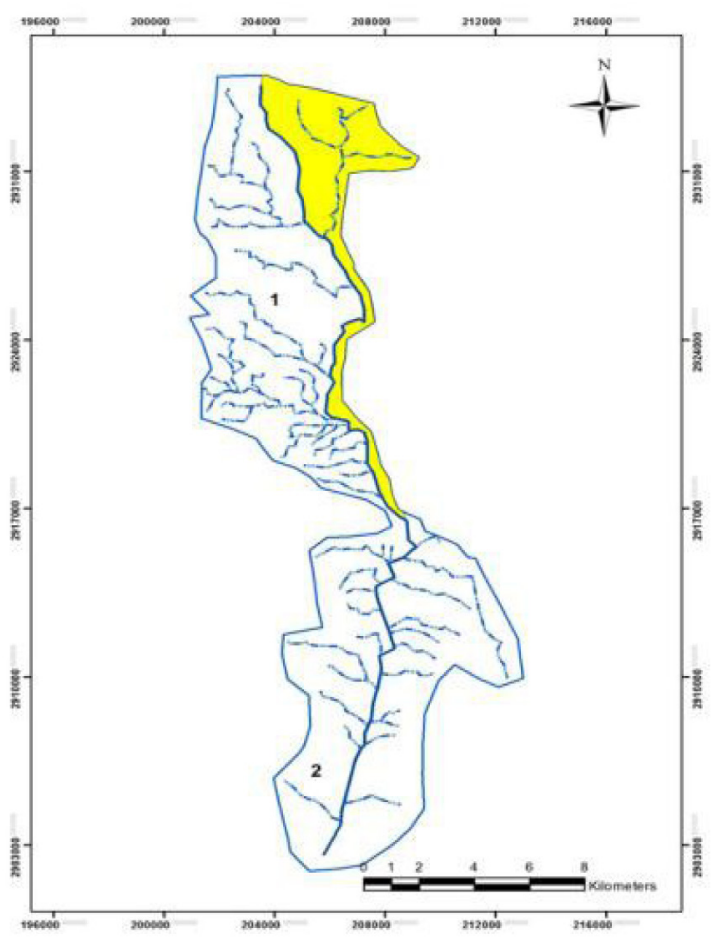

Figure 6. Evaluation of drainage asymmetry and tilting in sub-basin (1).

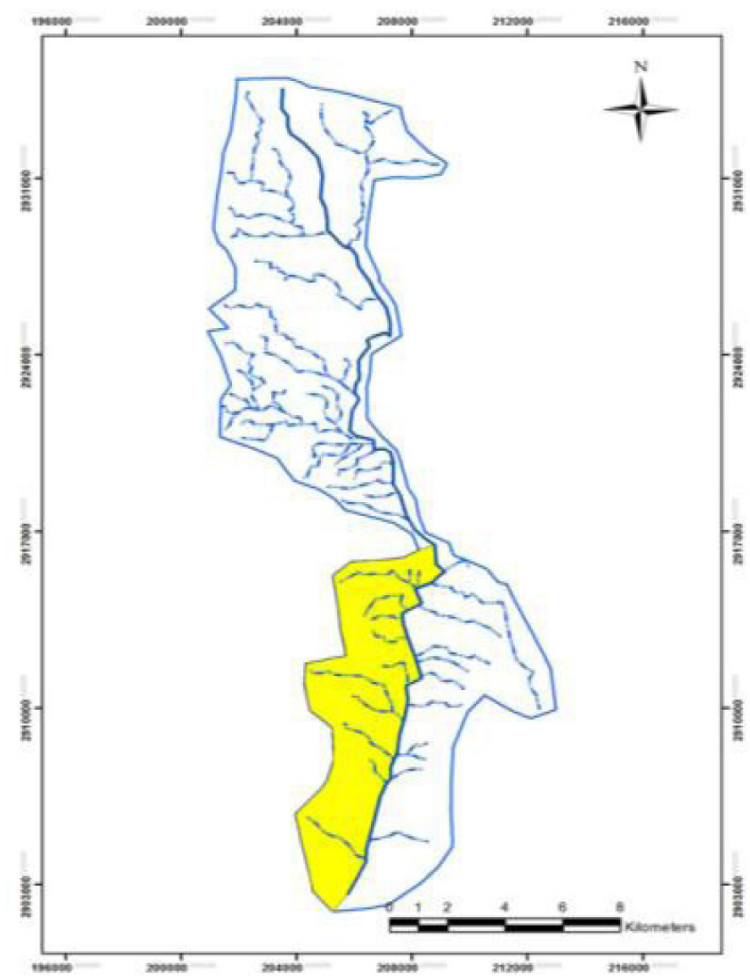

Figure 7. Evaluation of drainage asymmetry and tilting in sub-basin (2). 
The value of this index equals zero for a basin with complete symmetry. As asymmetry increases, the T value also increases and closes to $1^{10}$. In the studied area, T value or transverse topographic asymmetry is determined for both sub-basins and the results are presented in Table 4. Positions of the areas for which $T$ value is determined are indicated in Figure 8.

Evaluating drainage basin symmetry using transverse topographic asymmetry factor indicates that $\mathrm{T}$ value equals 0.33 in sub-basin (1) and 0.44 in sub-basin (2). As a result, sub-basin (2) shows higher asymmetry than subbasin (1).

Table 4. T value in sub-basins (1) and (2)

\begin{tabular}{lcccc}
\hline Basin & Da $(\mathrm{m})$ & Dd $(\mathrm{m})$ & $\mathrm{T}(\mathrm{m})$ & $\mathrm{T}_{\text {ave }}(\mathrm{m})$ \\
\hline 1 & 808.9 & 3233 & $\mathrm{~T}_{1}=0.25$ & $\mathrm{~T}_{1,2}=0.33$ \\
1 & 794.6 & 1889 & $\mathrm{~T}_{2}=0.42$ & \\
2 & 1149 & 2952 & $\mathrm{~T}_{1}=0.38$ & $\mathrm{~T}_{1,2}=0.44$ \\
2 & 1066 & 2097 & $\mathrm{~T}_{2}=0.50$ & \\
\hline
\end{tabular}

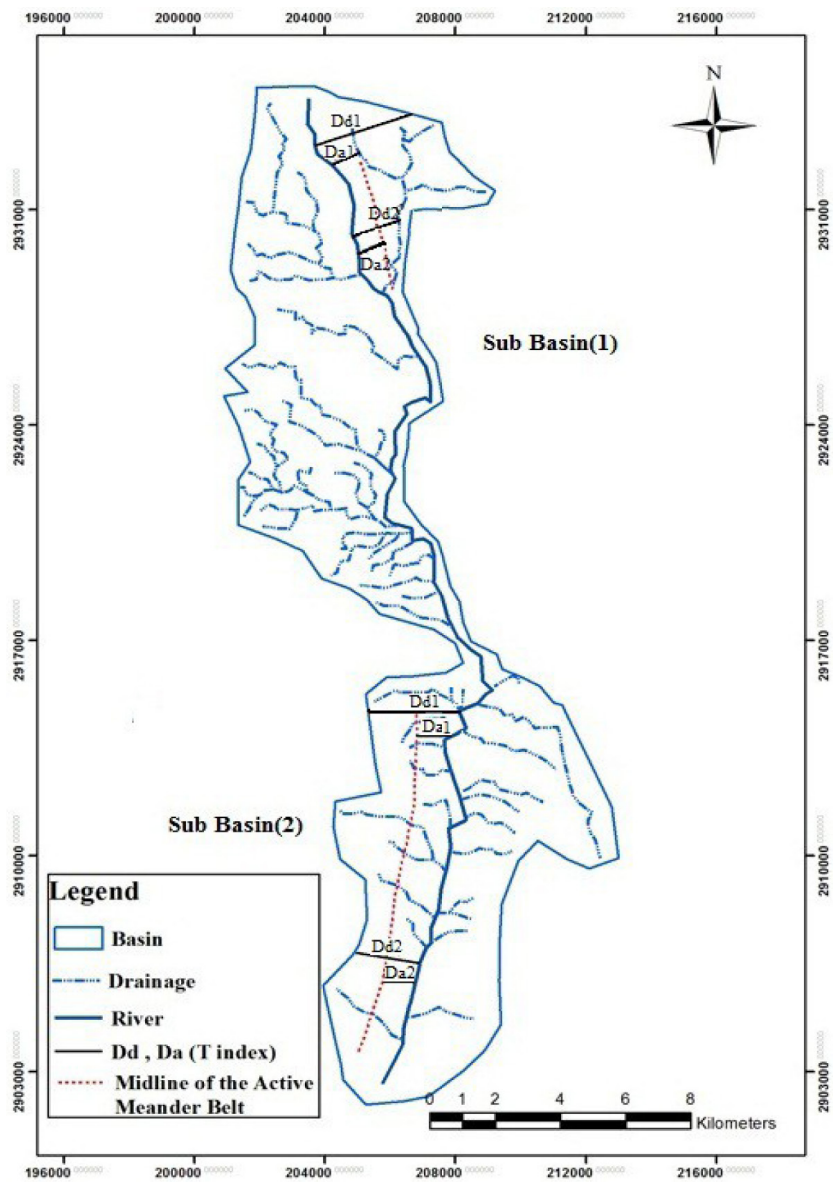

Figure 8. Position of the areas for which $\mathrm{T}$ value is determined.

\subsection{Stream Length Gradiant Index}

Stream Length Gradiant Index is obtained based on equation $4^{10}$ :

$$
\mathrm{SL}=(\mathrm{AH} / \mathrm{AL}) \cdot \mathrm{L}
$$

SL: Stream Length Gradiant Index, $(\Delta \mathrm{H} / \Delta \mathrm{L})$ channel slope or gradiant of the studied area, $(\Delta \mathrm{L})$ changes in channel length, $(\Delta \mathrm{H})$ changes in channel height, L: total length of channel

Parameters relating to SL are determined and calculated using topographic maps (Figure 9)

Thresholds of SL index are classified into three classes 5: in class 1 (tectonically active), SL $\leq 500$, in class 2 (with average tectonic activity), SL $\geq 300>500$, in class 3 (with low tectonic activity), $\mathrm{SL}<300$. The high value of SL in an area points to the tectonic activity of that area ${ }^{10}$. The highest SL value is observed in sub-basin (1), indicating the high tectonic activity there. The maximum and minimum SL values determined in sub-basin (1) and (2) fluctuate from 15-912 and 37-448, respectively. This index fluctuates more in sub-basin (1) than sub-basin (2), revealing

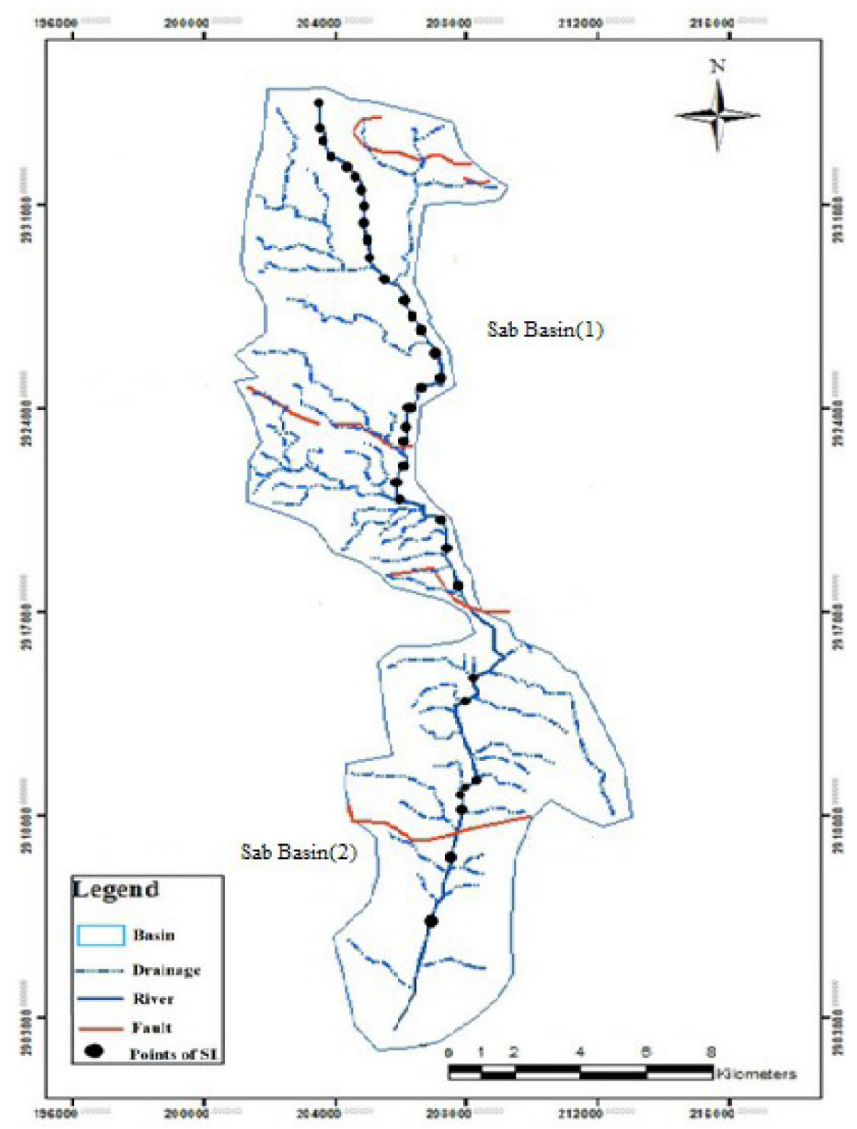

Figure 9. Locations where SL index is determined in sub-basin (1) and (2). 
high tectonic activity there (Table 5). Low fluctuations in SL index suggest that tectonic activities are dominated by alluvial processes.

\subsection{Mountain-Front Sinuosity index}

Mountain-Front Sinuosity index is obtained through the following equation ${ }^{10}$ :

$$
\mathrm{S}_{\mathrm{mf}}=\mathrm{L}_{\mathrm{mf}} / \mathrm{L}_{\mathrm{s}}
$$

$\mathrm{S}_{\mathrm{mf}}:$ Mountain-Front Sinuosity index, $\mathrm{L}_{\mathrm{mf}}$, mountainfront length and curvature recognized in its range, $\mathrm{L}_{s}$ Straight-line length of the mountain front.

The rate of Mountain-Front Sinuosity relates to the active tectonic and protrusion rate and if this rate is intense, the $\mathrm{S}_{\mathrm{mf}}$ value will be low. As protrusion rate decreases or stops, erosion processes are responsible for shaving mountain front and thus, $S_{\mathrm{mf}}$ increases. Practically, $\mathrm{S}_{\mathrm{mf}}$ value can be easily calculated through topographic or aerial images (Figure 10 and 11). $\mathrm{S}_{\mathrm{mf}}$ index in the areas with high tectonic activity is lower than 1.5 and in those areas with low or mid activity is higher than 11.5 ${ }^{10}$. The mid values for $\mathrm{S}_{\mathrm{mf}}$ index in segments $\mathrm{A}, \mathrm{B}$ and $\mathrm{C}$ are $1.09,2.1$ and 2.23 respectively. Therefore, mountain fronts in segment A are among the active ones (Table 6) and segments $\mathrm{B}$ and $\mathrm{C}$ are placed at the first tectonic place (Table 7 and 8) since their $\mathrm{S}_{\mathrm{mf}}$ value is higher than 1.5. The results indicate that segment $A$ is the most active part of the catchment. In addition, the tectonic activity rate has increased from segment $\mathrm{C}$ towards segment $\mathrm{A}$.

\subsection{Ratio of Valley - floor to Valley Height}

Ratio of valley-floor to valley height $\left(\mathrm{V}_{\mathrm{f}}\right)$ is calculated through the following equation ${ }^{10}$.

$$
V_{f}=2 V_{f w} /\left[\left(E_{L d}-E_{s c}\right)+\left(E_{r d}-E_{s c}\right)\right]
$$

$\mathrm{V}_{\mathrm{f}}$ is Ratio of valley-floor to valley height, $\mathrm{V}_{\mathrm{fw}}$ is valleyfloor, $\mathrm{E}_{\mathrm{ld}}$ and $\mathrm{E}_{\mathrm{rd}}$ are height of right- and left-hand walls of the valley and $\mathrm{E}_{\mathrm{sc}}$ is valley height.

$\mathrm{V}_{\mathrm{f}}$ is computed in sub-basin (1) and in segments (A) and (B). Segment $A$ has higher $V_{f}$ than segment B, however, height of basin floor and walls in segment $B$ is higher than that of segment A (Figure 12).

$\mathrm{V}_{\mathrm{f}}<1$ suggests active tectonic, $1.5>\mathrm{V}_{\mathrm{f}}>1$ suggests a relatively active tectonic and $\mathrm{V}_{\mathrm{f}}>1.5$ is marked with $\mathrm{U}$-shape

Table 5. SL value in sub-basin (1) and (2), and class type of tectonic activity in these sub-basins

\begin{tabular}{lccccc}
\hline $\begin{array}{l}\text { Class of tectonic } \\
\text { activity }\end{array}$ & $\begin{array}{c}\text { Number of } \\
\text { data }\end{array}$ & Average SL & Max SL & Min SL & Sub Basins \\
\hline 2 & 28 & 342.73 & 914.66 & 15.72 & Basin 1 \\
3 & 7 & 231.31 & 448 & 37.3 & Basin 2 \\
\hline
\end{tabular}

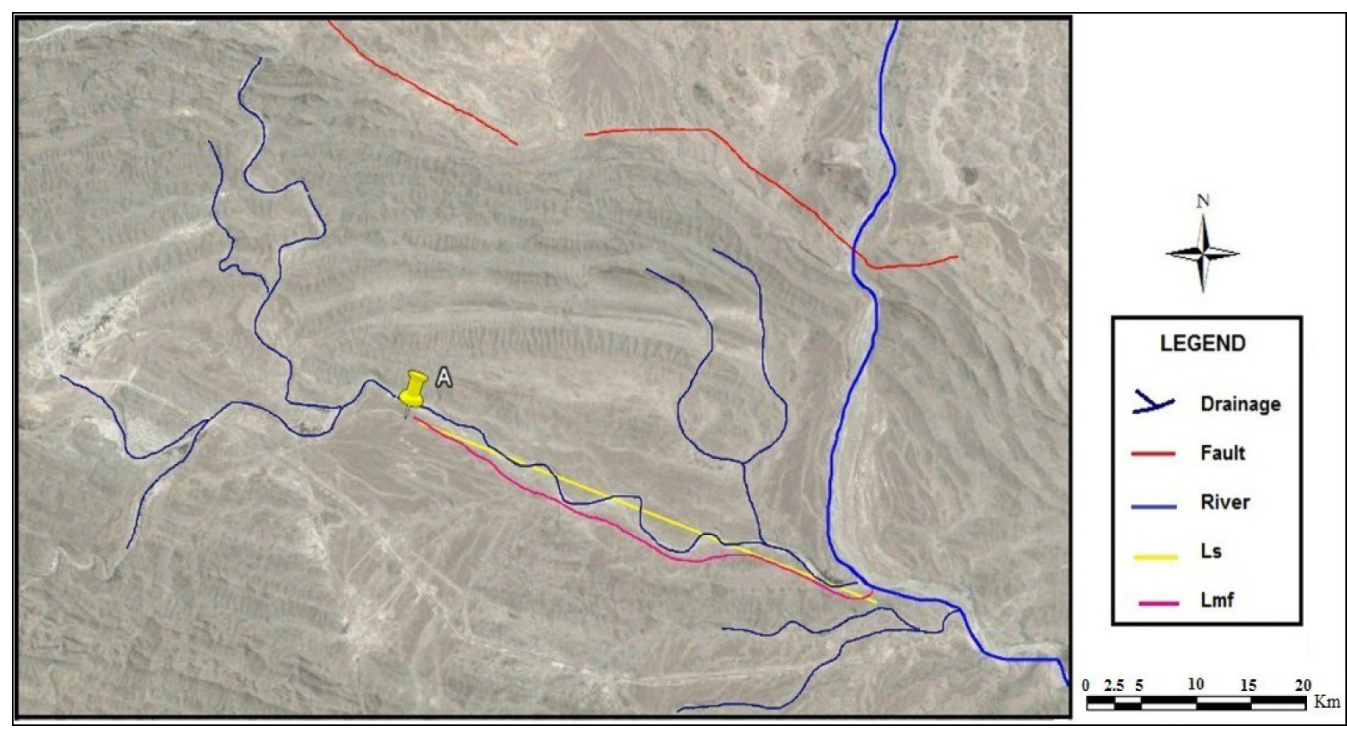

Figure 10. Location of segment A, $S_{m f}$ in sub-basin (1), using satellite photos taken by Google Earth (2013). 


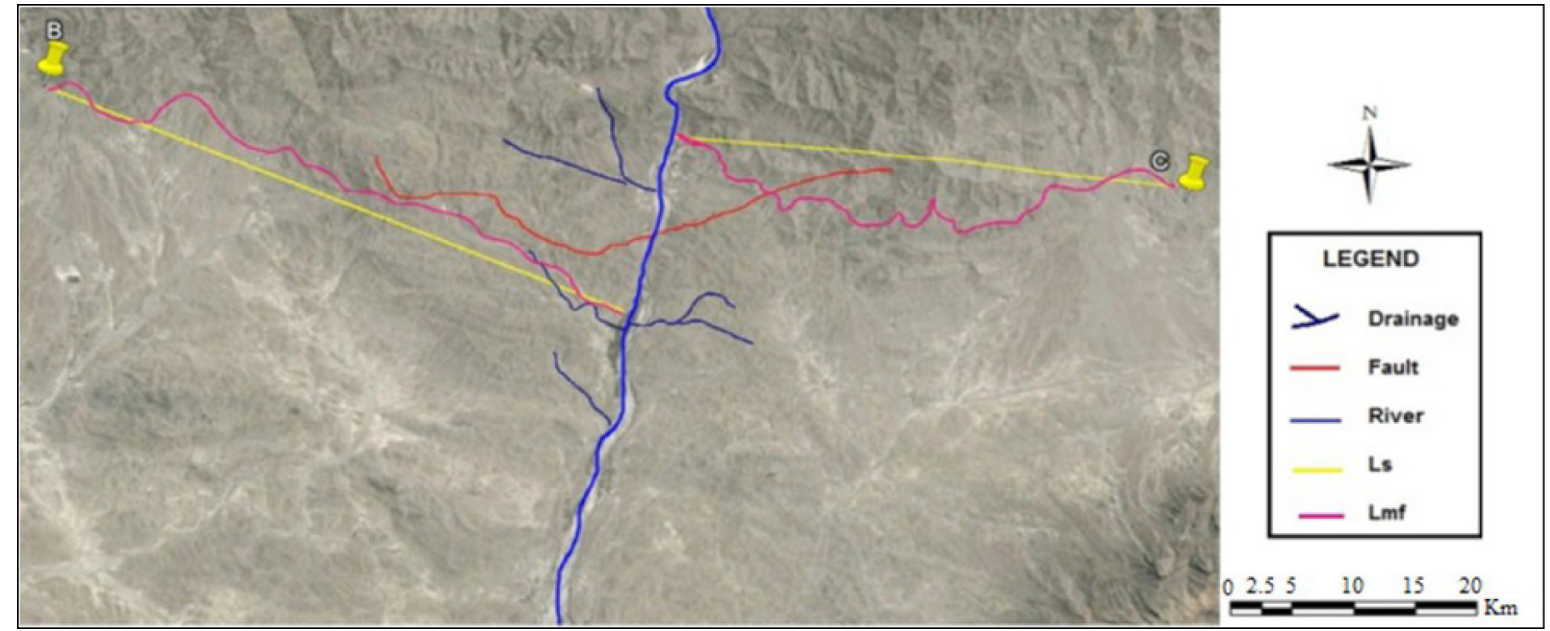

Figure 11. Location of segment B and C, $\mathrm{S}_{\mathrm{mf}}$ in sub-basin (2), using satellite photos taken by Google Earth (2013).

Table 6. The value of $S_{m f}$ index for measured segments in sub-basin (1)

\begin{tabular}{lccc}
\hline Segment & $\mathrm{L}_{\mathrm{mf}}(\mathrm{m})$ & $\mathrm{L}_{\mathrm{s}}(\mathrm{m})$ & $\mathrm{S}_{\mathrm{mf}}(\mathrm{m})$ \\
\hline $\mathrm{A}$ & 2208 & 2018 & 1.09 \\
\hline
\end{tabular}

Table 7. The value of $\mathrm{S}_{\mathrm{mf}}$ index for measured segments in sub-basin (2)

\begin{tabular}{lccc}
\hline Segment & $\mathrm{L}_{\mathrm{mf}}(\mathrm{m})$ & $\mathrm{L}_{\mathrm{s}}(\mathrm{m})$ & $\mathrm{S}_{\mathrm{mf}}(\mathrm{m})$ \\
\hline $\mathrm{B}$ & 7470 & 3708 & 2.01 \\
$\mathrm{C}$ & 11800 & 5280 & 2.23 \\
\hline
\end{tabular}

Table 8. The value of $S_{m f}$ index for the whole river catchment in the studied area

\begin{tabular}{lllll}
\hline Sub Basin & $\mathrm{L}_{\mathrm{mf}}(\mathrm{m})$ & $\mathrm{L}_{\mathrm{s}}(\mathrm{m})$ & $\mathrm{S}_{\mathrm{mf}}(\mathrm{m})$ & Average \\
\hline $1(\mathrm{~A})$ & 2208 & 2018 & 1.09 & \\
$2(\mathrm{~B})$ & 7470 & 3708 & 2.01 & 1.77 \\
$2(\mathrm{C})$ & 11800 & 5280 & 2.23 & \\
\hline
\end{tabular}

valleys ${ }^{10}$. The $\mathrm{V}_{\mathrm{f}}$ value is lower than 1 in sub-basins (1) and (2) and its value in segment B shows the minimum value, indicating an active area (Table 9 and 10).

\subsection{Meandering Index (Sinuosity and Tortuosity Coefficient)}

To keep the slope of the river balanced and regarding the tectonic changes leading to valley-slope change, the tortuosity of the river is moved as well. The secondary effect of this adjustment is the movement of the river from one curvature to another and the rate of meander and floodplain movement speeds up. Therefore, one can conclude that this secondary effect can be used as a tool

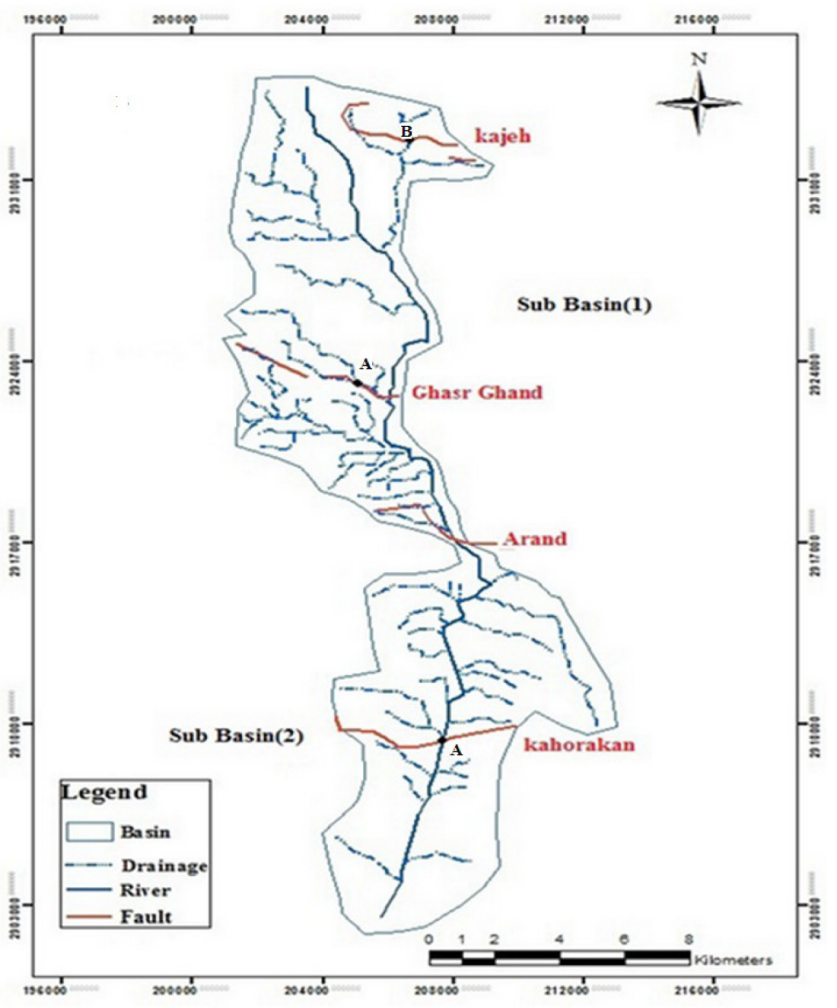

Figure 12. Position of the areas for which $V_{f}$ value is determined in sub-basin (1) and (2).

for detecting areas enjoying young tectonic activities ${ }^{11}$. Accordingly, highly tortuous rivers are close to equilibrium while straight course of the river points to the youngness and neotectonic activities of the area ${ }^{13}$. In this case, meandering index (sinuosity and tortuosity coefficient) and the following equation can be used:

$$
\mathrm{S}=\mathrm{C} / \mathrm{V}
$$


Table 9. $\mathrm{V}_{\mathrm{f}}$ value in sub-basin (1)

\begin{tabular}{lcccccc}
\hline Sub Basin (1) & $\mathrm{V}_{\mathrm{fw}}(\mathrm{m})$ & $\mathrm{E}_{\mathrm{ld}}(\mathrm{m})$ & $\mathrm{E}_{\mathrm{rd}}(\mathrm{m})$ & $\mathrm{E}_{\mathrm{sc}}(\mathrm{m})$ & $\mathrm{V}_{\mathrm{f}}(\mathrm{m})$ & $\begin{array}{c}\text { Activ tectonic } \\
\text { assessment }\end{array}$ \\
\hline A & 16 & 740 & 720 & 704 & 0.61 & up \\
B & 35 & 980 & 960 & 868 & 0.34 & up \\
\hline
\end{tabular}

Table 10. $\mathrm{V}_{\mathrm{f}}$ value in sub-basin (2)

\begin{tabular}{lcccccc}
\hline Sub Basin (2) & $\mathrm{V}_{\mathrm{fw}}(\mathrm{m})$ & $\mathrm{E}_{\mathrm{ld}}(\mathrm{m})$ & $\mathrm{E}_{\mathrm{rd}}(\mathrm{m})$ & $\mathrm{E}_{\mathrm{sc}}(\mathrm{m})$ & $\mathrm{V}_{\mathrm{f}}(\mathrm{m})$ & $\begin{array}{c}\text { Activ tectonic } \\
\text { assessment }\end{array}$ \\
\hline $\mathrm{A}$ & 39 & 600 & 560 & 534 & 0.84 & up \\
\hline
\end{tabular}
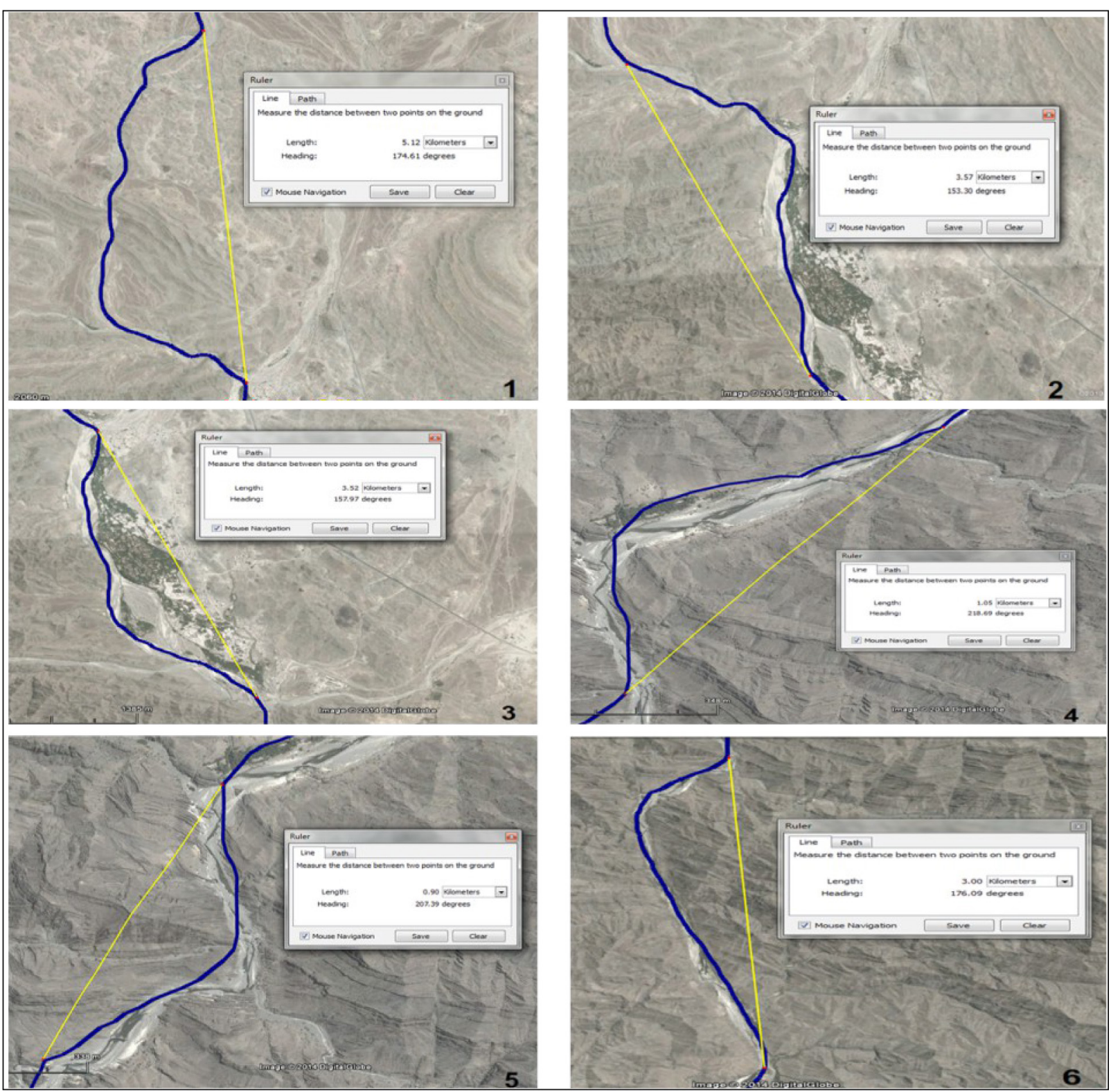

Figure 13. The selected meandering locations of Tang-e-Sarhe River for calculating the sinuosity index using satellite images taken by Google Earth (2013). 
S: rate of sinuosity or tortuosity of the river, C: river or stream length, V: valley length between the apex of two sequential meanders. An increase in the obtained values suggests the river is close to equilibrium while a decrease proves the high tectonic activities of the area ${ }^{12}$. Having studied the six areas indicating meandering tortuosity, the sinuosity rate of Tang-e-Sarhe river is calculated (Figure 13).

Employing equation (1) and Petts index, this study calculated the tortuosity coefficient (sinuosity value) of six meanders in Tang-e-Sarhe river and the resulting value varies from 1.19 to 1.33 . Accordingly, the maximum value of sinuosity is determined as 1.33 for a meander in sub-basin (1). Generally, the tortuosity coefficient of this river is 1.24 (Table 12).

Regarding tortuosity coefficient, Petts 9 classified rivers into 4 types (Table 13). According to our findings and petts tortuosity coefficient, most part of the river stream is sinuous. Tang-e-Sarhe River is a sinuous river with tortuosity coefficient of 1.24 (Table 13).

\section{Conclusion}

To investigate the quantitative and qualitative indices of morphometrics and active tectonic parameters, Tang-eSarhe catchment is studied in the form of two sub-basins. Lithological studies of the area indicate that some values of the SL index are not fully reliable and its high value is likely to be rooted in lithology. $S_{\mathrm{mf}}$ index reveals that

Table 12. Sinuosity index in Tang-e-Sarhe River

\begin{tabular}{lccc}
\hline Area & $\begin{array}{c}\text { Channel Lengh } \\
(\mathrm{C}) \mathrm{Km}\end{array}$ & $\begin{array}{c}\text { Valley Lengh } \\
(\mathrm{V}) \mathrm{Km}\end{array}$ & $\begin{array}{c}\text { Sinuousity } \\
(\mathrm{S}) \mathbf{k m}\end{array}$ \\
\hline 1 & 6.81 & 5.12 & 1.33 \\
2 & 4.43 & 3.57 & 1.24 \\
3 & 4.22 & 3.52 & 1.19 \\
4 & 1.32 & 1.05 & 1.25 \\
5 & 1.1 & 0.9 & 1.22 \\
6 & 3.63 & 3 & 1.21 \\
\hline
\end{tabular}

sub-basin (1) enjoys higher tectonic activity than subbasin (2). Transverse topographic symmetry values and geomorphic evidence point to the presences of tilting in both sub-basins. Calculation of $V_{f}$ shows that this value decreases from upstream to downstream. This value varies from 0.34 in sub-basin (1) to 0.84 in sub-basin (2), indicating a gradually decreasing tectonic activity trend. The high value of AF index in sub-basin (1) $(\mathrm{AF}=75.12)$ as well as its tilting towards east suggest that this tilting is resulted from intense folding and thrusting caused by high tectonic activities of the area. Examining the sinuous meandering morphometric index (tortuosity coefficient) of Tang-e-Sarhe river (equal: 1.24) points to the sinuosity of this river in most parts. However, the maximum rate of tortuosity (equal: 1.33) is recognized in sub-basin (1). Regarding the calculated morphometric indices, sub-basin (1) shows higher tectonic activity than sub-basin (2). According to geomorphological indices, the results of the present study indicate that neotectonic activities of the area are active while not equal everywhere.

\section{References}

1. Aghanabati, A., Geology of Iran. Geological survey of Iran, 2(Ed), 2006;586p.

2. Arian, M., and Maleki, Z., Neotectonic. Geological research center of Farazamin, 2009;96p.

3. Asghari, H., Active tectonic of Tange Sarhe-Nikshahr, unpublished M.A thesis, department of basic sciences, Islamic Azad University, research and sciences branch, Tehran, 2010; 187p.

4. Dolati, A., (2006), Structural study of Makran foldand-thrust belt, Unpublished M.A thesis, Islamic azad University, Tehran branch.

5. Dehbozorgi, A., Quantitative analysis of relative tectonic activity in the Sarvestanarea, central Zagros, Iran, Geomorphology, 2010; 21, 329-341.

6. Eftekhar-Nezhad, J, McCall, G., (1993), Explanatory text of the Nikshahr quadrangle Map 1:250000, Geological survey of Iran.

Table 13. Classification of rivers based on tortuosity coefficient (Petts, 1986)

\begin{tabular}{|l|l|l|l|}
\hline $\begin{array}{l}\text { Tortuosity } \\
\text { coefficient }\end{array}$ & $1-1.05$ & $1.06-1.25$ & \\
\hline River shape & & & \\
\hline Kind the river & Direct & Sinuousity & Meandering \\
\hline
\end{tabular}


7. Goorabi, A., and Nohegar, A., Geomorphological evidence of active tectonic of Darake catchment. Journal of Natural Geographical Studies, 2005;60, 96-177.

8. Maghsudi, M, and Kamrani, H ., Evaluating the effect of active tectonic in regulating river channel, a case study: Tajan river. Journal of Natural Geographical Studies, 2008;66, 37-55.

9. Petts,G., Water quality characteristics of regulated rivers, Progress in Physical Geography,1986;10, 492-516.

10. PourKermani, M., and Solgi, A., Morphotectonic, Islamic Azad University, research and sciences branch, Tehran, 2009;187p.
11. Telvari, A., Preliminaries of engineering and organizing rivers, Abkhiz publication. Agricultural Ministry of Iran. 2009;454p.

12. Yemani, M, Hossein zadeh, M., Examining the tortuous pattern of Tallar river using central angle and curvature coefficients. Journal of Natural Geographical Studies, 2007;73, 144-154.

13. Yemani, M., Alaei talghani, M., and Shahbazi, S., Morphotectonic and its effect on bed changes and pattern of Gharehsu river. Journal of Geography and Regional Development, 2011;17,125-143. 